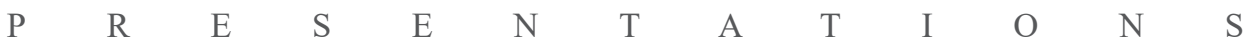

PAMIĘTNIK TEATRALNY 2020/4 (276)

ISSN 0031-0522, e-ISSN 2658-2899

INSTYTUT SZTUKI PAN

DOI: $10.36744 /$ pt.567

\title{
Ruthie Abeliovich
}

University of Haifa

ORCID: 0000-0003-4121-9693

\section{ON GUILT AND GHOSTS}

\author{
O winie i duchach
}




\begin{abstract}
This paper reviews Grzegorz Niziołek thought-provoking book The Polish Theatre of the Holocaust (London: Methuen Drama Press, 2019), and the key questions and issues it addresses. Focusing on Polish perspectives, theatrical representations and performative reactions to the extermination of the Jews during WWII, the book analyzes six decades of theatrical creation. Within this scheme, the victims and perpetrators are casted in the role of actors, while the Polish people are allotted the role of passive spectators, witnesses to the atrocity. This review sheds light on the ethical and aesthetical implications of Niziołek's study, by attending to the material aspects of the catastrophe, and its theatrical representations. It seeks to recuperate and integrate the Jewish perspective into the theatrical analysis.
\end{abstract}

Keywords: Polish theater after 1945, Holocaust, Shoah, Dybbuk, Szymon An-sky

\begin{abstract}
Abstrakt: Tekst omawia prowokującą do myślenia książkę Grzegorza Niziołka The Polish Theatre of the Holocaust (London 2019; oryginalne wydanie: Polski teatr Zagta$d y$, Warszawa 2013) oraz kluczowe pytania i problemy, które zostały w niej poruszone. Koncentrując się na polskich perspektywach, przedstawieniach teatralnych i performatywnych reakcjach na Zagładę Żydów podczas II wojny światowej, książka Niziołka analizuje sześćdziesiąt lat historii polskiego teatru. W ramach przyjętej przez autora perspektywy ofiary i sprawcy są aktorami, a Polakom przydzielona zostaje rola biernych widzów, świadków okrucieństwa. Artykuł rzuca nowe światło na etyczne i estetyczne implikacje badań Niziołka, zwracając uwagę na materialne aspekty katastrofy i jej teatralnych przedstawień. Stawia sobie także za cel odtworzenie i włączenie do analizy teatralnej żydowskiego punktu widzenia. (Przet. E. Olechnowicz)
\end{abstract}

Słowa kluczowe: teatr polski po 1945, Holokaust, Zagłada, Dybuk, Szymon An-ski 
Grzegorz Niziołek, The Polish Theatre of the Holocaust, translated by Ursula Phillips (London: Methuen Drama Press, 2019)

Th n 1988, Andrzej Wajda staged Szymon An-sky's (the pen name of Shlomo Zanvil Rappoport (1863-1920) signature play The Dybbuk, or Between Two Worlds in Polish, at the Old Theater (Stary Teatr) in Kraków. This was not the first time that the play had been staged in Poland. The Vilna Troupe had premiered The Dybbuk in Warsaw on December 1920. ${ }^{1}$ Since then, An-sky's drama has been produced more than any other Jewish play - in different languages and venues across the globe - attracting massive audiences. ${ }^{2}$

Among the Dybbuk's most famous productions, its Hebrew performance stands out. It was staged by Habima under the Russian Armenian director Yevgeny Vakhtangov, with scenography by Nathan Altman and music by Yoel Engel. This production, which debuted in Moscow on January 13, 1922, was renowned for its theatrical rendering of the traditional East-European Jewish community, its folklore and daily habits: many dramatic scenes featured religious rituals, folk songs, tunes, local stories, and social conventions customary to the Jewish life that - within two decades - would vanish forever from the European cultural and social scene.

1 For more on An-sky as an epitome of the modern Jewish experience, and the dybbuk as a theatrical manifestation of the complex modern Jewish condition, see Seth L. Wolitz, "Inscribing An-sky's Dybbuk in Russian and Jewish Letters," in The Worlds of S. An-sky: A Russian Jewish Intellectual at the Turn of the Century, eds. Gabriella Safran and Steve J. Zipperstein (Stanford: Stanford University Press, 2006), 164-202; Sylvie Anne Goldberg, "Paradigmatic Times: An-sky's Two Worlds," in The Worlds of S. An-sky: A Russian Jewish Intellectual at the Turn of the Century, eds. Gabriella Safran and Steve J. Zipperstein (Stanford: Stanford University Press, 2006), 44-53; Nathaniel Deutsch, "Thrice Born; or, Between Two Worlds: Reflexivity and Performance in An-sky's Jewish Ethnographic Expedition and Beyond," in Going to the People: Jews and the Ethnographic Impulse, ed. Jeffrey Veidlinger (Bloomington: Indiana University Press, 2016), 27-45.

2 For an elaborate discussion of the Vilna Troupe's production of An-sky's play, see: Michael C. Steinlauf, “'Fardibekt!' An-sky's Polish Legacy,” in The Worlds of S. An-Sky: A Russian Jewish Intellectual at the Turn of the Century, eds. Gabriella Safran and Steven J. Zipperstein (Stanford: Stanford University Press, 2006), 232-251; Debra Caplan, Yiddish Empire: The Vilna Troupe, Jewish Theater, and the Art of Itinerancy (Ann Arbor: Michigan University Press, 2018). 
The Jewish world depicted in An-sky's play perished in World War II, but Habima continued to stage The Dybbuk until $1965 .{ }^{3}$ Freddie Rokem accounts for the widespread staging of the play by pointing to the cultural relevance of the figure of the dybbuk - a distressed spirit of a dead person that speaks through the mouth of a living person in terms of the cultural significance of the dybbuk: "After the Shoah," Rokem explains, "there were six million potential dybbuks haunting the Jewish people, the state of Israel, as well as all of Europe, and maybe other parts of the world, too - constantly speaking through survivors." In other words, Habima's performance, from this point of view, transformed the sounds and images of these departed Jewish communities into a public lamentation on the extermination of European Jewry.

Polish performances of An-sky's play offer a different interpretation of the staged drama, and of the figure of the dybbuk. Wajda's 1988 theatrical adaptation of An-sky's play featured many Polish allusions, mainly by way of staging visual and dramatic images from Polish art and culture. Some twenty years later, in 2004, The Dybbuk was once again staged in Poland, this time by Krzysztof Warlikowski. Like Wajda, Warlikowski's production also emphasized the Polish loss by showing melancholic images of the perished Jewish world. Centering on the Polish audience and their response to the staged events, these performances drew on a bygone Jewish world in order to reflect upon postwar and post-Shoah sociopolitical transformation processes that Polish society had undergone since WWII. Specifically, as Grzegorz Niziołek argues in his book, these performances are examples of the way "Polish theatre, perhaps more than any other area of artistic creativity, became the space of powerful declarations relating to collective memory." Polish theater, according to Niziołek, reflected the profound tension

3 For more on Habima's 1922 production of The Dybbuk, see Ruthie Abeliovich, Possessed Voices: Aural Remains from Modernist Hebrew Theatre (Albany: SUNY Press, 2019), 49-84; Gad Kaynar, "National Theater as Colonized Theater: The Paradox of Habima," Theater Journal 50, no. 1 (1998): 14-16, https://doi.org/10.1353/tj.1998.0014; Shelly Zer-Zion, “"The Vilna Troupe': Prologue to the History of Habima," Bikoret ve-Parshanut, no. 41 (2009): 65-92; Shelly Zer-Zion, "The Dybbuk Reconsidered: The Emergence of a Modern Jewish Symbol Between East and West," Leipziger Beiträge zur Judischen Geschichte und Kultur 3 (2005): 175-197, https://doi.org/10.1515/9783110942323.175.

4 Freddie Rokem, "Has this Thing Appeared Again Tonight? Deus ex Machina and Other Interventions of the Supernatural," in Things: Religion and the Question of Materiality, eds. Dick Houtman and Birgit Meyer (New York: Fordham University Press, 2012), 136, https://doi.org/10.5422/fordham/9780823239450.003.0008.

5 Polish-Yiddish performances of Ansky's play took place in 1957, 1970, and 1973 at the Ester Rachel Kamińska State Jewish Theater in Warsaw, under the direction of Abram Morewski, Chewel Buzgan and Szymon Szurmiej. For further discussion of The Dybbuk on the Polish-Jewish stage, see Michael Steinlauf, "Dybbuks On and Off the Polish Jewish Stage," in The Jews in Poland, ed. Sławomir Kapralski, vol. 2 (Kraków: Judaica Foundation, 1999).

6 Grzegorz Niziołek, The Polish Theatre of the Holocaust, translated by Ursula Phillips (London: Methuen Drama Press, 2019), ebook, 133. 
between mourning and melancholia; between remembering and forgetting. On the one hand, Niziołek explains, the theater portrays Polish society as one that is profoundly affected by historical experience, always ready to grieve. However, on the other hand, the theater has accused Polish society of suffering from amnesia, depicting the past as an enigma. ${ }^{7}$

The figure of the dybbuk, as Zuzanna Dziuban avers, conveys the relational encounter of contemporary Poles with Jews, construed in their absence. ${ }^{8}$ Rather than hypostatize the memory of Jewish life and victims, Dziuban argues, the figure of the dybbuk in contemporary Polish culture epitomizes how the past haunts the Polish present. Polish performances of The Dybbuk thus demonstrate how theatrical representations of the past do not only refer to the ways in which we perceive bygone worlds, but also cast light on the present: on the ways we give voice to, and conceive of, events that shape our immediate presence. Through the creativity of theater and the fictionalization of history, the past is connected to the present.

Grzegorz Niziołek's The Polish Theatre of the Holocaust (translated by Ursula Phillips) focuses on Polish perspectives, theatrical representations and performative reactions to the extermination of the Jews during WWII. In its focus on the Polish viewpoint, this book raises an intriguing, critical question fraught with ethical repercussions: Is it possible to reflect upon Polish society and culture after WWII without centering on its various victims? Can we discuss events and images related to the extermination of the Jews from the standpoint of the observers and witnesses - and, by extension, of the theater audience - without tackling patterns of passive participation in the atrocities, as well as the suffering and agony they caused?

Niziołek's book addresses these questions through a rigorous study of six decades of theatrical responses to the Holocaust in Polish theater. The first part of the book examines how Polish theater portrayed the Holocaust, explicitly or implicitly. The second part surveys a range of theatrical performances by prominent Polish directors, including Leon Schiller, Jerzy Grotowski, Tadeusz Kantor, Andrzej Wajda, Krzysztof Warlikowski and Ondrej Spišák. In this section of the book, Niziołek describes the ways in which these directors confronted the experience of bearing witness, as well as the theatrical shaping of Polish history during WWII and in face of the extermination of European Jewry.

The Introduction to the book discusses what Niziołek identifies as one of the typical, perhaps "banal," incidents of the Shoah: the reaction of Polish passers-by to a

${ }^{7}$ Niziołek, The Polish Theatre of the Holocaust, 143.

${ }^{8}$ Zuzanna Dziuban, “Of Ghosts' (In)ability to Haunt: Polish Dybbuks," in The Spectral Turn: Imaginaire Jewish Ghosts in the Polish Post-Holocaust, ed. Zuzanna Dziuban (Bielefeld: Transcript Verlag, 2019), 131-184, https://doi.org/10.14361/9783839436295-006. 
Jew who unexpectedly appeared on a Warsaw street, having been driven by fear from his hideout. Although the example comes from Kazimierz Brandys's novel Samson, Niziołek does not treat it as fictional, thus anticipating his strategy of "treating theatre as a space for bearing witness and not for creating performances." Throughout the first part of the book, this example is repeatedly discussed in order to understand

the experience of the passers-by who positioned themselves as passive and powerless spectators, cast the disorientated Jew into the role of protagonist, the victim of a tragic spectacle, and fatalistically recognized the invisible perpetrators as a ruthless inevitability.

Niziołek argues that:

They therefore turned the incident, in which they participated, into theatre, with roles appropriate to it as well as uncrossable dividing lines between stage and auditorium, thereby endowing the situation with a false transcendence. ${ }^{10}$

Particular attention is thus paid to analyzing the public cultural sphere through the metaphor of the theater. Within this schematic, the victims and perpetrators are cast in the role of actors, while the Polish people are allotted the role of passive spectators, witnesses to the atrocity. However, the metaphor of the theater, as the author critically explains, is misleading because it defines Polish society as a society of bystanders. Before images of the Shoah made their way onto the stage, the theater provided a conceptual framework for defining the relationship between the victim, the victimizer and the bystander. ${ }^{11}$ Theater thus afforded ways for representing various modes of watching atrocities. In the book, Niziołek discusses various types of visual spectatorship through the effect of "wrong seeing" enacted in the theatre, and its affective reception: shock, heightened empathy or, conversely, indifference. The theatrical paradigm serves Niziołek in order to tackle some of the fundamentals of Polish reactions to the extermination of the Jews, namely the ethics of the gaze, the struggle with guilt and the denial of agency.

The book opens with the following declaration: "The most important thing is to realize that everything was visible, that it really did take place and that everyone saw at least a fraction of what was going on." This opening premise serves for Niziołek as a point of departure to address the denial of Polish participation in the Shoah, and to rule out widespread claims by Polish individuals that "they did not see or know" about the atrocities that were taking place on their very land. The need of the author to explicitly validate the fact that the mass, planned extermination of the Jews, and the scenes of their persecution, humiliation, exclusion and killing, were visible and public, attests to the presence and prevailing reliance on these false claims.

\footnotetext{
9 Niziołek, The Polish Theatre of the Holocaust, 30.

10 Niziołek, 31.

11 Niziołek, 210.
} 
The focus on the dynamics of knowing, seeing and participating in the Polish public sphere, as discussed in the book, lacks informative details: out of the eleven million human beings killed during the Shoah, six million were Polish citizens. Three million were Polish Jews; another three million were Christians. Most of the remaining victims were from other European countries, including Hungary, Czechoslovakia, Ukraine, Russia, Holland, France and even Germany. During the years spanning 1939-1945, the majority of the Jewish population that lived in Poland was exterminated. On the eve of the German occupation of Poland in 1939, 3.3 million Jews lived there, amounting to ten percent of the country's population. At the end of the war - in 1945 - approximately 380,000 Polish Jews remained alive - the rest had been murdered in the ghettos and the six death camps: Chełmno, Belzec, Sobibor, Treblinka, Majdanek and Auschwitz-Birkenau. However, between 130,000 and 200,000 Jews were killed by Polish citizens. ${ }^{12}$

The sheer numbers involved in this genocide are almost incomprehensible; they suggest a daily routine whereby people either were grabbed from their homes and families or publicly murdered. Cattle-train wagons stuffed with thousands of men, women and children traversed Poland, taking Jewish victims to the death camps. Furthermore, houses were burnt, Jewish property was looted or sold, and entire villages were emptied. The atrocities committed against Jews did not cease with the end of the war. According to estimations made by Andrzej Żbikowski, in the years following the end of the war, at least 750 Jews were killed by Polish citizens. ${ }^{13}$ These numbers and events speak for themselves: no one could have avoided the sights and smells, the daily atmosphere of fear and violence that enabled the overwhelming presence of the fatal mechanism which had operated in front of the eyes of Polish inhabitants for years. ${ }^{14}$ The extermination of the Jews, as Niziołek explains, "did not come as a moral shock to Polish society" nor did it

12 David Engel, "Poland Since 1939," in The YIVO Encyclopedia of Jews in Eastern Europe, ed. Gershon Hundert, vol. 2 (New Haven: Yale University Press, 2008), 1407; Wolfgang Benz (ed.), Dimension des Völkermords: Die Zahl der jüdischen Opfer des Nationalsozialismus (Munich: Deutscher Taschenbuch Verlag, 1996), 411-497; Israel Gutman, "Poland," in Encyclopedia of the Holocaust, ed. Israel Gutman (Jerusalem: Yad Vashem,1990), 1174-1175; Michael C. Steinlauf, Bondage to the Dead: Poland and the Memory of the Holocaust (Syracuse: Syracuse University Press, 1997), 23-42; Laura Jockusch, Collect and Record!: Jewish Holocaust Documentation in Early Postwar Europe (Oxford: Oxford University Press, 2012), 84.

13 Andrzej Żbikowski, " “Night Guard': Holocaust Mechanisms in the Polish Rural Areas, 1942-1945: Preliminary Introduction into Research," East European Politics and Societies 25, no. 3 (2011): 512-529, https://doi.org/10.1177/0888325411408073.

14 Klaus-Peter Friedrich, "Collaboration in a 'Land without a Quisling': Patterns of Cooperation with the Nazi German Occupation Regime in Poland during World War II," Slavic Review 64, no. 4 (2005): 711-746, https://doi.org/10.2307/3649910; Carla Tonini, "The Polish Underground Press and the Issue of Collaboration with the Nazi Occupiers, 1939-1944," European Review of History: Revue européenne d'histoire 15, no. 2 (2008): 193-205, https://doi.org/10.1080/13507480801931119. 
arouse sympathy - at the most, it triggered merely "feeble reactions of condemnation emanating from a feeling of imposed duty." 15 In other words, knowledge, sight or the lack thereof, are not to be found at the core of the issue.

Polish theater, as the book shows, did not deny the existence of the Shoah, but instead it deformed its memory, misrepresenting the role of Polish men and women in the extermination of the Jews, eschewing the fact that antisemitism was prevalent amongst the Polish masses, and that many of them endorsed the blood libel and anti-Semitic stereotypes. This outlook does not bring forth the voices of the victims of the Shoah. It does not center on the daily humiliation, traumatic pain, enduring suffering of Polish Jews, nor on the devastating consequences of the Shoah on Polish society. Rather, this point of view emphasizes the need to face one's guilt and accept blame in the aftermath of the calamity that befell the country.

Niziołek's choice of nomenclature vis-à-vis the naming of the events which marked the massive, planned extermination of the Jews during the Second World War is intriguing, revealing a glaring gap between the Polish original and its English translation. Niziołek opts to use the Polish word "Zagłada," which means "extermination." In the English version, however, Niziołek resorts to the established term the "Holocaust," loosely meaning "a sacrifice," and, more specifically, "a burnt offering." The term "holocaust" - as Giorgio Agamben explains - is euphemistic insofar as it means the "supreme sacrifice in the sphere of a complete devotion to sacred and superior motives." ${ }^{16}$ From this perspective, this denomination forges a linkage between death in the gas chambers and the idea of a sacrifice. ${ }^{17}$ The term "holocaust," according to Agamben, contains a "heredity that is from its inception anti-semitic." 18 Mostly, the term "holocaust" does not denote the notion of catastrophe, unlike the Hebrew term "Shoah," designating the destruction of over a thousand years of Jewish Polish life and culture. ${ }^{19}$

In his focus on the Polish theater of the Shoah, the author misrepresents the thousand-year history of Polish Jewish culture, including the prolific Jewish theater scene that existed before the war. What had been the largest Jewish community in the world became, by 1945, the smallest, and Poland - one of the most ethnically

${ }_{15}$ Niziołek, The Polish Theatre of the Holocaust, 374.

${ }^{16}$ Giorgio Agamben, Remnants of Auschwitz: the Witness and the Archive, trans. Daniel HellerRoazen (New York: Zone Books, 1999), 30.

${ }^{17}$ Agamben, 30.

${ }_{18}$ Agamben, 31.

19 On the etymology and meaning embedded in the term "holocaust," see: Heather Blurton, " The History of an Incorrect Term': Agamben, Etymology and the Medieval History of the Holocaust," Postmedieval 5, no. 3 (2014): 336-345, https://doi.org/10.1057/pmed.2014.24; Jon Petrie, "The Secular Word Holocaust: Scholarly Myths, History, and 20th Century Meanings," Journal of Genocide Research 2, no. 1 (2000): 31-63, https://doi.org/10.1080/146235200112409. 
diverse countries in Europe - became the most homogeneous. Niziołek, nevertheless, underscores the part played by theater in buttressing the state of denial vis-àvis the passive participation or even active role of Polish citizens in the atrocities perpetrated in Polish territory. Theater, as Niziołek points out, became an arena of repetition, where the very fact of denial has been produced and reproduced. ${ }^{20}$

Marvin Carlson's concept of theater as a "memory machine" 21 is overtly and covertly mobilized throughout the book in order to examine "replicated and culturally stabilized creative and perceptual procedures based on mechanisms of memory and repetition." 22 According to Niziołek, theater is a powerful cultural instrument geared at restricting one's field of visibility, distributing roles, and propagating cultural regimes. ${ }^{23}$ After the Shoah, Niziołek explains, the universal social experience of both witnessing and denying suffering, led to a deep transformation in the theater. ${ }^{24}$

How did this transformation materialize on stage? Repetition, as Carlson explains, fosters an active, embodied remembering that comes into being and transpires through laborious work and its performance. The making of theater - by actors or spectators - shapes the repetition and reproduction of visual and aural images, social ideas and practices, as a force maneuvered by agents and actors. Images from the war, and from the Shoah, are thus worked into the theater not only through its images and representational practices, but also through the identity of the actors, directors and scenographers, as well as through the very participation of audiences; those putting on the performances are not only representing a historical event, and the spectators are not only viewing it. The theatrical event itself is a form of agency, enabling active participation.

The Shoah, as Dori Laub argued, is an "event without witnesses." 25 That is, at the time when it was taking place, it made occupying the position of witness impossible. ${ }^{26}$ In other words, everyone participated in this event, be it as a passive observer, a victim or a perpetrator. This insight can also be projected onto the theatrical event: there are no passive spectators or actors in the theater - everyone involved assumes some degree of agency. Addressing the making of theater only through the standpoint of the director, Niziołek avoids the material aspects

20 Niziołek, The Polish Theatre of the Holocaust, 32-33.

21 Marvin Carlson, The Haunted Stage: The Theatre as Memory Machine (Ann Arbor: University of Michigan Press, 2003).

22 Niziołek, The Polish Theatre of the Holocaust, 33.

23 Niziołek, 33

24 Niziołek, 34

25 Dori Laub, “An Event Without a Witness: Truth, Testimony, and Survival," in Testimony: Crises of Witnessing in Literature, Psychoanalysis and History, eds. Shoshana Felman and Dori Laub (New York: Routledge, 1992), 75-92.

26 Laub, "An Event Without a Witness," 80. 
of theater-making, which are a lacuna in the book: who were the actors, scenographers and stage workers who participated and reproduced the images? Where they the same people that fostered the notion of denial? What sort of ideology and beliefs did they hold? And what did they do during the war and following it? A deep glance into the collaborative work of theater might enhance the ways in which we conceive the deep-seated connections between art and society, between social performances and political processes.

Written in lucid prose, and accompanied by dense theoretical explanations, Niziołek's book prompts its readers to profoundly question and engage with the issue of agency, from an ethical as well as a theatrical standpoint - to think of the mechanisms of representation, the emptied signifiers, distorted, denied and unspoken facets in contemporary Polish culture. This book provides a rich and highly thought-provoking reading experience. 